\title{
Sustainability of Business with Earth Sources in V4 Countries
}

\author{
Michal Cehlár ${ }^{1}$, Katarína Čulková ${ }^{1, *}$, Henrieta Pavolová ${ }^{1}$, and Samer Khouri ${ }^{1}$ \\ ${ }^{1}$ Technical University Košice, Faculty BERG, Letná 9, 04001 Košice, Slovakia
}

\begin{abstract}
Due to the availability of earth sources there is necessary to provide business sustainability that refers the effort of a company to reduce negative impacts on social, environmental and economic area. This can be search through various indexes that are directly or indirectly influencing effectiveness of any business, not excluding mining industry presenting base of industries in number of countries. The objective of the paper is to evaluate and compare business environment in area of earth sources in V4 countries according Global competitiveness index, Doing Business and Index of business environment with aim to identify obstacles that limit business development. From the results we can evaluate that business with earth sources has number of obstacles that company must overcome with aim that earth sources can be further sold at a favourable price. Business with earth sources in V4 could be improved by permanent development of innovation for increasing of effectiveness in area of mining and processing, as well as better conditions for starting businessmen.
\end{abstract}

\section{Introduction}

Business in the frame of single sectors is very complex, playing important role during creation of new possibilities for economic development and social stability, including various indexes that are directly or indirectly influence effectiveness of any business, not excluding mining industry, because business with earth sources presents base of industrial sector in Slovakia, as well as in other countries, mining of raw material is base element, providing necessary materials in any industrial sector for production of various products. The application of the process management philosophy is possible also for the mining industry [1]. The mining process is a process the realization of which is financially very demanding. Understanding and application of process management is a necessary condition in order to achieve the success of mining organization on the market. To assess the relationship between the quantity and quality of economic growth, the trends of social-andeconomic development of countries and regions, sustainability indicators are needed as targets for assessing the effectiveness of this development [2]. The mining industry is in constant development on every continent. The reason is increasing demand for raw materials. Despite many positive aspects, there is widespread concern from the general public or parliamentarians about the negative effects of mining activities. The highest dependence is between GDP, average wage, employment and wages in mining [3].

There is a lack in the research of mining and quarrying industry efficiency research in the Central and Eastern European region. In the frame of business with earth sources there 
is gap in the research [4]. But business and the economic aspects are very important key issue to be considered in order to understand future changes in energy systems [5]. Arshad et al. (2016) found evidence that high energy price decreases real interest rate, investment and stock prices [6]. Also Brown and Yücel (2002) surveyed linking fluctuations in energy prices to aggregate economic activity [7]. Cunado and Perez de Gracia (2005) studied the impact of oil price shocks on both economic activity and consumer price indexes [8]. Many societies today express their desire to participate in the decision-finding on the development of their economic environment. In this area Falck (2016) argues to make social licensing an integral element of economic (business risk) management for mining companies [9]. The last decade and a half has witnessed a dramatic growth in mining activity in many developing countries. The relationships between mining and political economic change had been studied as well [10]. Presently, energy conservation and pollution reduction became two of the most significant factors in economic development and social circulate [11]. Number of countries is struggling to understand, plan and realize the energy-environmenteconomic nexus [12]. There is therefore necessary to determine the key players in the coal mining industry, who are the beneficiaries of the process underpins the socio-economic attributes of the industry [13]. The objective of the paper is to evaluate and compare business environment in area of earth sources in V4 countries according chosen indicators with aim to identify obstacles that limit business development.

\section{Methodology}

Object of searching of business with earth sources present V4 countries - Slovakia, Czech Republic, Poland and Hungary. The countries are compared from the view of macroeconomic analysis - GDP, measure of unemployment, measure of inflation, number of companies and employment in mining sector. Due to the extension of the research we researched business with black and brown coal. In the frame of business environment analysis in V4 we used following indexes:

1. Global competitiveness index (GCI). Global competitiveness index combines 114 indexes, creating conceptions that are very important for productivity and long term development in the business. GCI index consists of weighted average of indexes that belong to 12 categories and that are ranked to three subcategories that present basic demands, increasing of effectiveness, innovation and sophisticated factors [14].

2. Doing Business. Doing Business presents statistic evaluation of big sample of economies, according evaluated questionnaire from World Bank. Obtained data show extend of obstacles that influences the business and at the same time also possible reforms and solutions for given obstacles. Ordering according achieved score of individual economies is moving around 1-190 [15].

3. Index of business environment. Business alliance of Slovakia makes the index for mapping of business environment that searches positive changes or finds area where certain measurements are necessary. The alliance creates own methodology for the index creation, where the base period of the index calculation is 1 st July 2001, when reference value was 100 points, since then business environment is evaluated quarterly [16].

Indexes are used in the case study; there is described complexity of the case and data of development, present state or other obstacles that could influence present state and development of the situation [17]. 


\section{Results and discussions}

Mining sector presents base element for fluent and developed industry, since the sector provides raw materials for production and participates at the activity of the state economy. In any country mining sector is different, since appearance of raw materials is not steady [18]. Presently number of organizations is dealing with competitiveness, following and comparing given business environment not only in Slovakia, but in whole Europe. Comparing of business environment in V4 can be done by main macro-economic indexes GDP, measure of unemployment or inflation in given period [19].

\subsection{Number of companies in mining sector}

According mentioned we compare how many companies are acting in V4 and what is the development of mining companies in time horizon 2012-2018. The development is illustrated by Figure 1 .

Table 1. Number of mining companies.

\begin{tabular}{|c|c|c|c|c|c|c|c|}
\hline GEO $\backslash$ TIME & $\mathbf{2 0 1 2}$ & $\mathbf{2 0 1 3}$ & $\mathbf{2 0 1 4}$ & $\mathbf{2 0 1 5}$ & $\mathbf{2 0 1 6}$ & $\mathbf{2 0 1 7}$ & $\mathbf{2 0 1 8}$ \\
\hline $\begin{array}{c}\text { Czech } \\
\text { Republic }\end{array}$ & 333 & 348 & 359 & 363 & 380 & 376 & 371 \\
\hline Hungary & 469 & 459 & 448 & 448 & 429 & 428 & 409 \\
\hline Poland & 1785 & 2014 & 1944 & 1657 & 1852 & 2008 & 2054 \\
\hline $\begin{array}{c}\text { Slovak } \\
\text { Republic }\end{array}$ & 108 & 138 & 125 & 157 & 182 & 187 & 223 \\
\hline
\end{tabular}

Source: own processing according [20]

Total number of companies in mining sector includes all companies, either mining of ore, non-ferrous, construction or other mineral resources (see Figure 1).

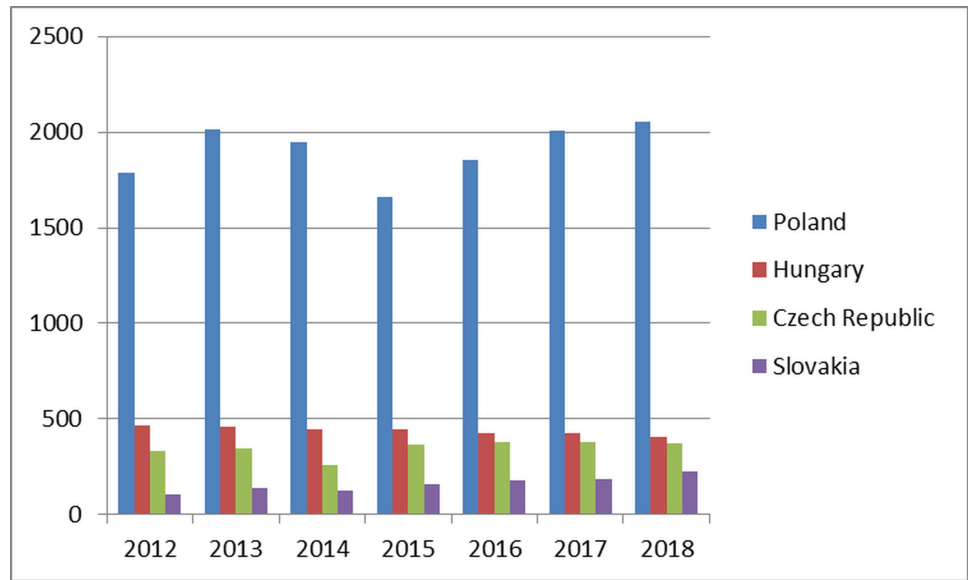

Fig. 1. Development of mining companies in V4.

Source: own processing according [20] 
From the previous figure we can evaluate the majority of mining companies is in Poland, but during last year the state has been considerably changing [21]. The least number of companies is in Slovakia, in spite of rapid growth in every year, while in 2018 223 mining companies had been registered.

\subsection{Employment in mining sector}

Employment presents growth or decrease of active inhabitants that find the job or they were dismissed due to the various reasons. In spite of possible growth of companies, employment does not need to grow also due to the workers fluctuation between companies. Employment in mining sector in V4 had been compared according data in Table 2.

Table 2. Employment development in mining sector.

\begin{tabular}{|c|c|c|c|c|c|c|c|}
\hline GEO $\backslash$ TIME & $\mathbf{2 0 1 2}$ & $\mathbf{2 0 1 3}$ & $\mathbf{2 0 1 4}$ & $\mathbf{2 0 1 5}$ & $\mathbf{2 0 1 6}$ & $\mathbf{2 0 1 7}$ & $\mathbf{2 0 1 8}$ \\
\hline $\begin{array}{c}\text { Czech } \\
\text { Republic }\end{array}$ & 47.8 & 46.0 & 43.1 & 40.8 & 35.4 & 37.6 & 38.5 \\
\hline Hungary & 12.3 & 12.3 & 10.3 & 8.9 & 10.7 & 10.2 & 9.3 \\
\hline Poland & 223.8 & 246.4 & 250.8 & 267.4 & 266.9 & 228.7 & 227.6 \\
\hline $\begin{array}{c}\text { Slovak } \\
\text { Republic }\end{array}$ & 13.9 & 11.6 & 12.6 & 11.5 & 9.5 & 11.8 & 10.9 \\
\hline
\end{tabular}

Source: own processing according [20]

Total development of employees' number in mining sector is illustrated by Figure 2, including all employees, participating at the research, exploration, single mining and processing, but also other employees of administrative activities of mining companies.

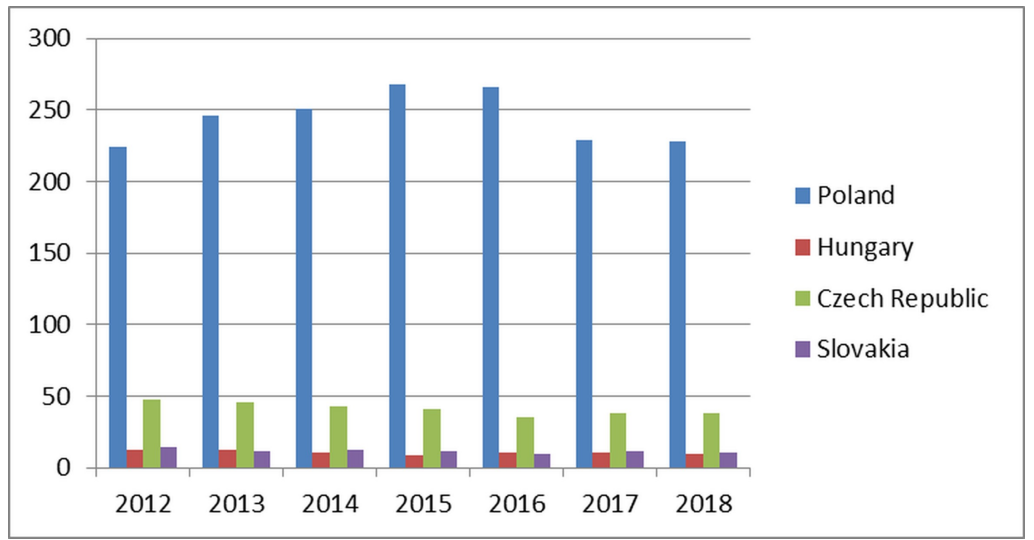

Fig. 2. Number of employees in mining sector (in thousands persons).

Source: own processing according [20]

From the development there is obvious that due to the growth of number of companies in Slovakia, also number of employees decreased and this decrease can be recorded also in Czech Republic [22]. On the other hand the highest number of employees is recorded in Poland that had the highest number of employees in 2015 with 267,4 thousand employees in mining and exploitation. Poland produces and exports the highest volume of coal in 
comparing with other V4 countries, and according IEA (2017) [23] Poland belongs to the 9th place among main coal producers of the world [24].

\subsection{Total evaluation of business with coal in V4}

From the general point of view we can evaluate that business with coal has number of obstacles that company must overcome with aim that mined coal can be further sold at a favourable price. The important obstacle is mostly shortage of financial means, while financial demands on surface mining is different from deep mining of coal, but also of other raw materials mined. As illustrated by Figure 3, the highest volume of mined coal is in Poland and the least volume is in Slovakia, from which results that Slovakia, but also Hungary, must import coal to cover domestic consumption of coal, while Poland and Czech Republic have sufficient volume of coal stocks [25].

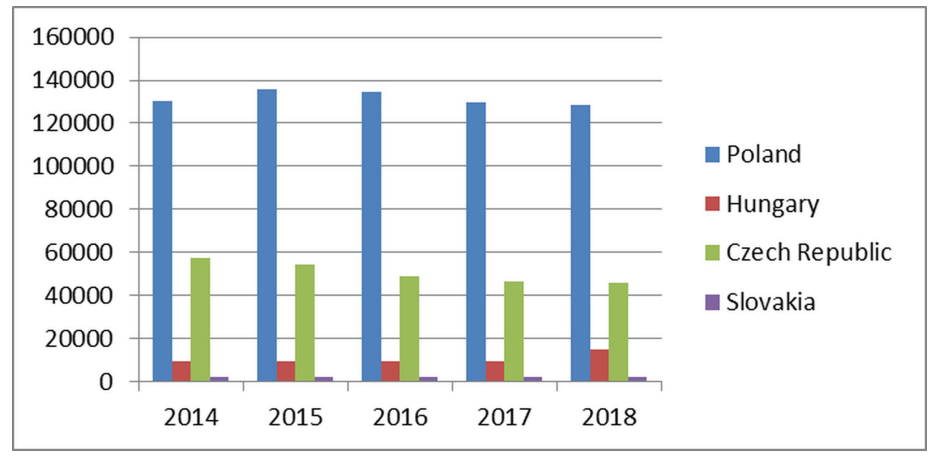

Fig. 3. Comparing of coal mining in V4.

Source: own processing according [20]

The reason of mining and production of coal decreasing in V4 is also the fact that protection of living environment is regarded in spite assumed stocks are for several decades or hundreds of years according volume of deposit in given country. Following Figure 4 shows development of black coal in annual intervals. In between 2008-2018 the highest price of black coal was registered in 2011 , on the other hand the lowest price had been registered in 2016. Presently in 2018 we can see growth of black coal prices.

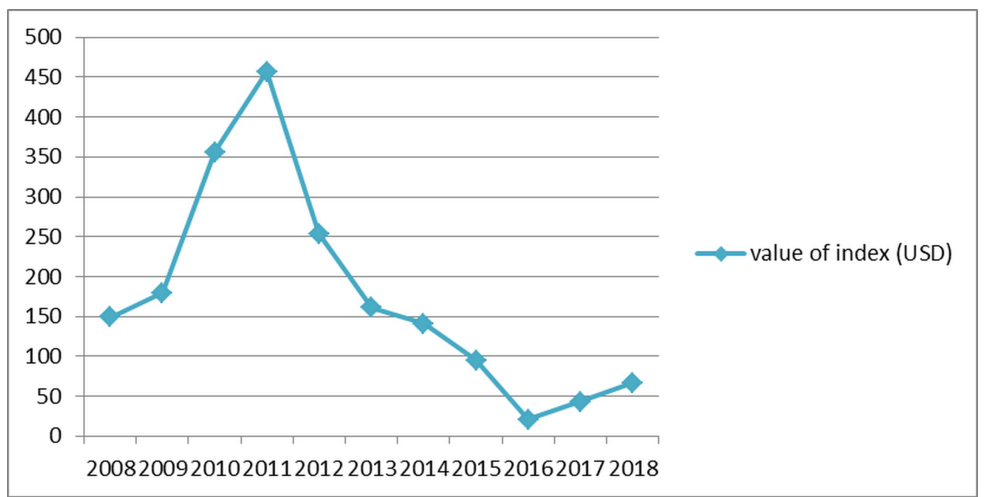

Fig. 4. Development of black coal prices as US index (in USD).

Source: own processing according [22] 
Prices of coal are developed mainly according market commodity, in spite coal belongs among raw materials that have certain technical and commercial characteristics [26]. The world market is mainly traded with coal, iron, manganese, gold, copper or zinc, but prices are different and developed according availability and deliverability of given raw material. While on regional market there is prevailing business mainly with brown coal, kaolin, construction material and other raw materials, when their deposits are available almost in any country, therefore their price is the rather lower.

\section{Conclusions}

According analysis and results of business environment in mining sector, comparing in V4 there are certain differences. In business, it does not matter in what the company makes business and if the business is prospering, but mainly rather in what are determined certain legislative measurements and support of starting businessmen [27]. Suggestion of measurements that are necessary for improving of business environment assumes is given also by ministries in given countries. There is necessary mainly sufficient informing of businessmen that must always follow up all laws and legislation. Evaluation of business environment in V4, but also in other countries is varied according various influences, affecting single business environment. In mining sector development of the business could be influenced by new technologies and innovations, resulting in growth of mining companies, when companies could mine rather higher volume of raw materials due to the new technology or innovation from previously heavy available deposits. At the same time business in mining sector in V4 could be improved by: permanent development of innovation for increasing of effectiveness in area of mining and processing, as well as better conditions for starting businessmen. Proper business environment needs to be competitive. Competitors could be only such businessman that is interesting about his own business. Therefore there is necessary to find and permanently compare the competition, but also to try to improve own business according new ideas.

Contribution is partial result of projects solving VEGA MŠVVaŠ SR 1/0515/18 „The decisionmaking model of process of evaluating raw material policy of regions" and VEGA 1/0651/2018

"Research of institutional environment influence to the corporate social responsibility, consumers satisfaction and performance of the company".

\section{References}

1. ড̌. Markulik, Š., M. Cehlár, M., R. Kozel, Acta Montanistica Slovaca. 23:1, 46-52 (2018)

2. L. Domaracká, M. Torres, N. Fonseca, A. Sokolova, M. Yazevich, E3S Web Conferences. 41, 02018 (2018)

3. M. Taušová, K. Čulková, L. Domaracká, C. Drebenstedt, M. S. Muchová, J. Koščo, A. Behúnová, M. Drevková, B. Benčöová, Acta Montanistica Slovaca. 22:4, 359-367 (2017)

4. J. Straková, P. Pártlová, J. Váchal, Acta Oeconomica Universitatis Selye. 6:1, 155-166 (2017)

5. T. Nakata, Process in Energy and Combustion Science, 30:4, 417-475 (2014)

6. A. Arshad, M. Zakaria, X. Junyang, Renewable and Sustainable Energy Reviews, 55, 25-33 (2016) 
7. S.P.A. Brown, M. K. Yücel, Quarterly Review of Economics and Finance, 42:2, 193208 (2002)

8. J. Cunado, F. Perez de Gracia, Quarterly Review of Economics and Finance, 45:1, 65$83,(2005)$

9. W.E. Falck, Mineral Economics, 29, 97-104 (2016)

10. A. Bebbington, L. Hinojosa, D.H. Bebbington, M.L. Burneo, X. Warnaars, Development and Change, 39:6, 887-914 (2008)

11. D. Liu, X. Yang, X. Tian, R. Wu, L. Wang, Procedia Environmental Sciences, 5, 120$130(2011)$

12. S.A. Ur Rehman, Y. Cai, N.H. Mirjat, G.D. Walasai, M. Energy Policy, 1, 200-211 (2019)

13. K. Mathu, R. Chinomona, Mediterranean Journal of Social Sciences, 4, 347-358 (2013)

14. K. Schwab, The Global Competitiveness Report 2017-2018 (Hope Steele, Geneva, 2017)

15. World bank, Doing Business Rating, URL: http://www.doingbusiness.org/ /media/WBG/DoingBusiness/

16. R. Coronto, J. Dlhopolček, P. Kopečný, R. Maxin, V. Tonka, J. Tvrdoň, E. Vajdová, T. Vyšný, Analysis, monitor of business environment quality in SR and competitiveness of the economy (Centrum vzdelávania Bratislava, 2014)

17. K. Fuchsová, Case study - definition (Prešovská univerzita v Prešove, Prešov, 2006)

18. R. Lacko, Z. Hajduová, H. Pavolová, Acta Montanistica Slovaca. 22:2, 136-145 (2017)

19. K. Belanová, BIATEC: Bratislava, 22:1, 12-17 (2014)

20. Eurostat-2018, URL: http://ec.europa.eu/eurostat/en/data/browse-statistics-by-theme

21. I. Jonek-Kowalska, Resource Policy, 60, 169-177 (2019)

22. Development of coal prices at the market (Kurzy CZ, Praha, 2018)

23. IEA-2017, Key world's energetic statistics, URL: https://www.iea.org/publications/freepublications/publication/KeyWorld2017.pdf

24. R. Bońda, D. Brzeziński, M. Czapigo-Czapla, A. Malon, S.Z. Mikulski, W. Miśkiewicz, S. Oszczepalski, D. Siekiera, L. Skrzypczyk, J. Sokolowksi, J. Stawierej, K. Szamalek, W. Szczygielski, M. Szuflicki, M. Tymiński, A. Walkuska, Bilans zasobów zlóś kopalin w Polsce, 1, 36-53, (2016)

25. Balance of raw materials stocks in Hungary, URL: http://www.mbfh.hu/home/html/ index.asp? $\mathrm{msid}=1 \&$ sid $=0 \&$ hkl $=72 \& \operatorname{lng}=1$

26. Association of world coal, URL: https://www.worldcoal.org/coal

27. Z. Tóth, L. Mura, Economic Development and Management of Regions, V, 424-429 (2014) 